\title{
KAJIAN IKONOGRAFI DAN IKONOLOGI LUKISAN A. ARIFIN MALIN DEMAN II
}

\author{
Nessya Fitryona \\ nessyafitryona@ymail.com
}

\begin{abstract}
Abstrak
Lukisan Malin Deman II adalah salah satu karya dari seniman A.Arifin yang memiliki visual yang unik. Penelitian ini bertujuan untuk mengidentifikasi motif artistik, konsep dan tema serta nilainilai simbolik yang terdapat dalam lukisan tersebut. Pendekatan yang digunakan adalah ikonografi dan ikonologi Erwin Panofsky. Hasil penelitian menunjukkan motif artistik yang ada di dalam lukisan tersebut adalah kegairahan seniman untuk merepresentasikan bentuk estetik tubuh perempuan dengan gaya fantasi. Tema dalam lukisan tersebut adalah penindasan kaum laki-laki terhadap kaum perempuan dengan konsep dasar tentang konflik antar gender. Nilai simbolik yang terdapat pada karya tersebut adalah pergeseran posisi perempuan Minangkabau dan gejala penyimpangan moral.
\end{abstract}

kata kunci : ikonografi, ikonologi, lukisan "Malin Deman II"

\begin{abstract}
Painting Malin Deman II is one of the art works of artists, A.Arifin, who have a unique visual. This study aims to identify the artistic motifs, concepts and themes and symbolic values contained in the painting. The approach used iconography and iconology Erwin Panofsky. The results showed an artistic motif that is in the painting is excitement artist to represent form of female body aesthetic with fantasy style. Themes in the painting is the oppression of men and women with the basic concept of conflict between gender. Contained symbolic value of these works is a shift in the position of Minangkabau women and symptoms of moral aberration.
\end{abstract}

Keywords : iconography and iconology, painting "Malin Deman II"

\section{Pendahuluan}

Keberadaan corak seni lukis dalam konstelasi perjalanan seni rupa selalu tumpang tindih. Artinya, dalam suatu periode waktu bukan berarti perkembangan seni lukis yang telah dicapai masa sebelumnya dinyatakan berakhir dan masuk pada pembabakan selanjutnya. Salah satunya dapat dilihat dalam perkembangan seni lukis di Sumatra Barat.

Seiring diperkenalkan dan masuknya pengaruh seni rupa modern melalui sekolah Belanda yang didirikan pada akhir abad ke-19, wilayah ini telah berkembang corak yang sangat dominan dalam kehidupan seni lukisnya, yaitu corak naturalistik. Perkembangan ini dapat diamati hingga tahun 80-an bersamaan dengan perupa yang berkarya dengan corak seni rupa modern lainnya dan mulai melakukan alternatif lain dalam berkarya seni secara sporadik.

Setelah masuknya wacana dan praktik seni rupa yang menunjukkan kecenderungan pada seni rupa kontemporer di awal tahun 2000, tidak banyak pelukis yang tetap konsisten pada corak naturalistik. Terutama di kalangan pelukis dan perupa mudanya. 
Corak naturalistik dan penyekatan pada praktik-praktik seni rupa modern lainnya dianggap tidak lagi dapat memenuhi kebutuhan seniman sebagai kreator untuk berekspresi lebih bebas dan terbuka pada kemungkinan-kemungkinan baru.

Para pelukis lebih banyak mulai membebaskan diri dalam gaya dan material dengan memberi muatan karya ke arah sosial politik, ekonomi, dan budaya. Pergeseran paradigma berkesenian ini juga terjadi pada beberapa perupa dan pelukis senior di Sumatra Barat. Di antara fenomena tersebut, jiwa naturalis masih dapat dilihat pada segelintir seniman. Salah satunya pada pelukis A. Arifin.

A. Arifin adalah seorang seniman kelahiran Bukittinggi, 22 Desember 1943. Ia seniman otodidak tamatan Sekolah Teknik di Padang dan mulai aktif melukis sejak tahun 1975 (Zon, 2013: 7). Arifin memandang lukisannya sebagai sebuah dokumentasi dari alam dan kultural di masyarakat. Namun, tidak seperti pelukis naturalis lain, karyanya tidak hanya dapat dinikmati secara visual tetapi juga dapat dipahami proses atau muatan isi yang tersirat dibalik itu (Pamola, 2013 : 4). Terdapat satu lukisan yang cukup menarik pada sebuah pameran tunggalnya yang diadakan di Rumah Budaya Fadli Zon, tanggal 30 Oktober - 8 November 2013. Karya tersebut adalah lukisan yang berjudul Malin Deman II (2003).

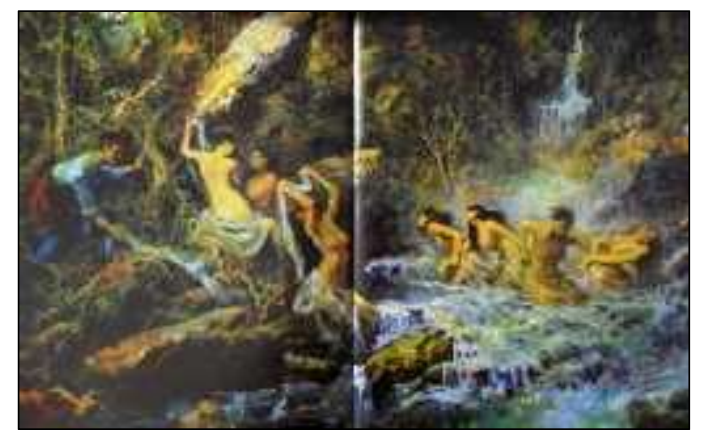

Gambar 1. Malin Deman II (2013), cat minyak di atas kanvas, 155,5 x $96 \mathrm{~cm}$ Sumber : Katalog Pameran Tunggal A. Arifin (Foto reproduksi : penulis, 2013)

Representasi lukisan tersebut memperlihatkan sebuah keunikan. Lukisan ini terlihat berbeda dari karya-karya lukis A. Arifin yang umumnya bertemakan bentangan alam dan gadis Minang. Visualisasi dari karya tersebut terdapat kesamaan antara cerita rakyat Minangkabau dengan cerita rakyat yang ada Jawa. Selain itu, lukisan sebagai artefak dari kebudayaan yang diproduksi oleh pelukis khususya yang melalui proses erkarya di Sumatra Barat, dapat dikatakan jarang sekali yang merepresentasikan keerotisan tubuh perempuan yang membuka aurat ke atas kanvasnya. Lukisan ini memperlihatkan sebuah upaya yang berbeda dan keluar dari arus utama yang berkembang pada seniman-seniman di Sumatra Barat. Kalaupun ada yang melukiskan tubuh wanita secara terbuka dan erotis, itupun hanya muncul secara sporadik dan direpresentasikan tidak secara lugu melainkan didistorsikan seperti dalam bentuk abstrak.

Berkaitan hal tersebut, lukisan Malin Deman II (2013) secara tekstual dan kontekstual berkaitan dengan visualisasi karya dengan juga menurut pada sejarah seni dan kebudayaan yang relevan sehingga tercipta karya seni yang demikian. 
Penelitian ini menggunakan pendekatan ikonologi dan ikonografi Erwin Panofsky. Maka permasalahan yang terdapat pada lukisan Malin Deman II (2013) yaitu pertama, bagaimana secara tekstual lukisan tersebut memuat penanda faktual dan ekspresional sehingga diketahui motif artistik dalam lukisan. Kedua, apa konsep dan tema yang mengonstruksi lukisan tersebut sehingga memiliki tipe yang berbeda dengan karya lukisan lainnya yang mengangkat tema yang sama dalam visualisasinya serta mempunyai kesan menarik, unik, dan bermakna. Ketiga, apa nilai-nilai simbolik di balik lukisan tersebut. Demikian, dengan menjawab permasalahan tersebut diharapkan dapat menambah wawasan dan apresiasi terhadap ungkapan makna dalam perspektif disiplin ilmu khususnya terhadap karya seni yang dikaji.

\section{Ikonologi Ikonografi Panofsky}

Ikonografi (iconography) secara etimologi berasal dari bahasa Yunani yang terdiri dari kata aekon yang berarti gambar dan graphe yang berarti tulisan. Ikonografi merupakan cabang dari kajian sejarah seni yang berkaitan dengan pokok bahasan atau makna dari karya seni (Panofsky 1955: 26). Pendekatan ini muncul pada abad ke-19. Tokoh-tokoh tersebut di antaranya Emilie Male, N.P. Kondadov, Hugo Kehrer, dan Erwin Panofsky. Ikonografi dalam perkembangannya merupakan suatu kajian tentang isi atau muatan simbolik dan budaya yang meliputi aspek, politis, religius, filosofis, dan sosial yang terkait dengan karya seni rupa.

Kajian ikonografi mengungkapkan makna yang tersembunyi di balik konfigurasi gambar atau suatu bentuk karya seni. Panofsky mengemukakan terdapat tiga tahap dalam melakukan pendekatan ikonografi, yaitu tahapan deskripsi praikonografi (preiconography description), analisis ikonografis (iconographical analysis), dan interpretasi ikonologi (iconological interpretation) (Panofsky, 1955: 26-40). Ketiga tahapan tersebut merupakan hirarki tahapan yang saling berkaitan untuk menjawab permasalahan yang dikaji. Tahap-tahap ikonografi dan ikonologi Panofsky dirangkum dalam tabel berikut :

\begin{tabular}{|l|l|l|}
\hline No. & Objek Interpretasi & Aksi Interpretasi \\
\hline I. & $\begin{array}{l}\text { Pokok bahasan primer atau alami (a) } \\
\text { faktual, (b) ekspresional, menyusun } \\
\text { dunia motif artistik }\end{array}$ & Deskripsi pra-ikonologi \\
\hline II. & $\begin{array}{l}\text { Pokok bahasan sekunder atau } \\
\text { konvensional, menyusun dunia } \\
\text { gambar, cerita, dan alegori }\end{array}$ & Analisis ikonografi \\
\hline III. & $\begin{array}{l}\text { Makna intrinsik atau isi, menyusun } \\
\text { dunia nilai "simbolis" }\end{array}$ & Interpretasi ikonologis \\
\hline
\end{tabular}

Tabel 1. Tahap-Tahap Kajian Ikografi dan Ikonologi Sumber : Panofsky, 1995: 40 


\begin{tabular}{|l|l|l|}
\hline No. & Alat Interpretasi & $\begin{array}{l}\text { Prinsip Korektif dari } \\
\text { Interpretasi (Sejarah Tradisi) }\end{array}$ \\
\hline I. & $\begin{array}{l}\text { Pengalaman praktis (rasa familier } \\
\text { dengan objek dan peristiwa) }\end{array}$ & $\begin{array}{l}\text { Sejarah seni (pandangan menurut } \\
\text { kondisi sejarah yang bervariasi, } \\
\text { objek dan peristiwa dinyatakan } \\
\text { oleh bentuk) }\end{array}$ \\
\hline II. & $\begin{array}{l}\text { Pengetahuan tentang sumber literal } \\
\text { (rasa familier dengan tema dan } \\
\text { konsep khusus) }\end{array}$ & $\begin{array}{l}\text { Sejarah tipe/jenis (pandangan } \\
\text { terhadap di mana, di bawah } \\
\text { kondisi sejarah yang bervariasi, } \\
\text { tema dan konsep khusus } \\
\text { dinyatakan melalui objek dan } \\
\text { peristiwa) }\end{array}$ \\
\hline III. & $\begin{array}{l}\text { Intuisi sintesis (rasa familier } \\
\text { dengan tendensi esensial dari } \\
\text { pikiran manusia); dikondisikan } \\
\text { oleh psikologi personal dan } \\
\text { "weltanschaumg" }\end{array}$ & $\begin{array}{l}\text { Sejarah gejala kultural } \\
\text { (pandangan di bawah kondisi } \\
\text { sejarah yang bervariasi, tendensi } \\
\text { umum dan esensial dari pikiran } \\
\text { manusia dinyatakan melalui tema } \\
\text { dan konsep khusus) }\end{array}$ \\
\hline
\end{tabular}

Tabel 2. Kerangka Konfirmasi Kajian Ikonografi Ikonologi (Sumber : Panofsky, 1955: 41)

\section{Deskripsi Praikonografi}

Tahap deskripsi praikonografi merupakan tahap awal yang mengacu pada aspek tekstual karya seni. Tahap ini terdiri dari identifikasi makna faktual dan ekspresional untuk mengetahui motif artistik dari karya yang disebut makna primer. Makna faktual merupakan cara pengidentifikasian bentuk yang tampak pada objek yang berasal dari konfigurasi unsur-unsur rupa yang dipresentasikan oleh objek. Sedangkan makna ekspresional berasal dari empati dalam menafsirkan suasana atau ekspresi dan objek yang diamati berdasarkan rasa familier terhadap objek dan peristiwa. Makna primer merupakan bentuk murni atau membaca yang tampak pada objek, meliputi garis, warna, bentuk, dan teknik serta material yang digunakan dalam merepresentasikan objek-objek alami seperti manusia, binatang, tanaman, peralatan, dan sebagainya (Panofsky, 1955: $33)$.

Tahap deskripsi praikonografi secara keseluruhan akan dikoreksi melalui prinsip korektif kondisi sejarah seni yang bervariasi. Hal ini disebut sejarah gaya atau sytle yang sinkron dengan objek (Panofsky, 1955: 40). Tahap deskripsi praikonografi pada kajian lukisan Malin Deman II (2013) merunut pada penguraian aspek tekstual visual dengan cara mendeskripsikan identitas fisik yang dapat diamati secara faktual dalam lukisan.

Lukisan Malin Deman II berukuran 155,5 x $96 \mathrm{~cm}$ terbuat dari media cat minyak di atas kanvas. Lukisan ini memvisualisasikan suasana sungai berbatu di tengah hutan rimba yang tidak jauh dari air terjun kecil di bagian belakangnya. Hutan rimba tersebut divisualisasikan seperti masih atau jarang dijamah manusia dengan pohon-pohon dan semak-semak yang rapat tanpa celah menutupi sungai. 
Selanjutnya lukisan tersebut merepresentasikan figur tujuh perempuan yang sedang mandi dan seorang pria di balik pepohonan. Gestur tujuh perempuan divisualisasikan dengan gerakan yang dinamis dan erotis. Tujuh orang perempuan tersebut diposisikan dengan cara empat orang berada di tengah aliran sungai dan tiga orang berada di pinggiran sungai. Perempuan yang sedang mandi tersebut divisualkan tanpa busana dengan bertelanjang dada. Mereka hanya dilukiskan berbalut selendang putih transparan yang menutupi bagian bawah. Sebelah kiri lukisan terlihat seorang pria dengan mengenakan busana beridentitas budaya Minang. Pria tersebut mengenakan baju lengan tiga perempat dan sarawa (celana) biru muda dengan sarung merah, selanjutnya seluk atau destar berwarna merah di kepalanya. Ia berada di balik pepohonan dengan tubuh bungkuk mencondongkan badannya ke arah sungai. Tangan kirinya bertumpu pada pohon dan tangan kanannya seolah berusaha menjangkau sehelai selendang putih yang berada di atas batu pinggir sungai.

Analisis data tahap ini memerlukan analisis struktur seni meliputi unsur-unsur visual dan pengorganisasian elemen rupa dalam pengamatan. Untuk itu diperlukan teori struktur seni. Salah satunya yang dikemukakan oleh Edmund Burke Feldman. Menurut Feldman sebuah struktur seni dapat diidentifikasi dengan memfokuskan perhatian terhadap garis, bentuk, warna, tekstur, serta gelap terang yang merupakan bagian dari ujud objek/gambar (Feldman, 1991: 164). Berkaitan dengan analisis formal yaitu unsur-unsur visual gramatika pada karya lukisan A.Arifin, unsur-unsur visual seni rupa yang dianalisis berupa tampilan garis, bentuk, warna, dan tekstur yang dapat diamati secara nyata.

Secara teknis karya lukisan ini digarap dengan raut garis lurus, lengkung, bertumpuk (pointilis), dan zig-zag dengan kontrol spontan namun cermat. Penggarapan garis dapat diamati dilakukan dalam suasana hati yang emosional dengan susunan garis ekspresif. Ini terlihat pada sapuan kuas pada figur objek perempuan dan gerakan air yang menghantam bebatuan. Selain itu, juga terlihat pada penggarapan batang pohon, ranting dan daun.

Garis-garis memiliki kesan berat, kasar, kuat, dan tegas. Bentuk-bentuk dalam lukisan Malin Deman II merupakan aplikasi bentuk yang biomorfis dari manusia. Tujuh figur perempuan dan satu orang pria di sisi kiri lukisan dapat diamati sumber dari bentuk dasar oval, petak, dan segitiga yang bersifat kurvalinear. Sedangkan bidang dalam lukisan tidak ditemukan berbentuk dua dimensi dan bersifat geometris seperti lukisan kubistis dan karya arsitektural melainkan memiliki kesan volum sehingga berbentuk tiga dimensional.

Pewarnaan dalam lukisan Malin Deman II cenderung menampilkan perwakilan warna alam, dan memiliki kesan lebih gelap. Warna dominan yang digunakan dapat diamati dari penggunaan warna primer seperti kuning yang hampir tampak pada setiap sisi lukisan baik dalam penggarapan unsur-unsur warna alam dan kulit pada figur manusia yang dilukiskan. Warna kuning merupakan warna yang paling mencolok di antara beberapa warna yang lain. Sehingga warna kuning menjadi warna yang mendominasi lukisan Arifin. Jika diamati, terdapat dua warna komplementer yang disandingkan untuk membentuk gradasi yang tidak linear, seperti pada warna kulit dan gradasi pohon dalam lukisan. Warna tersebut adalah warna merah yang disejajarkan dengan hijau, warna biru disejajarkan dengan orange. Warna-warna dibiarkan tidak bercampur rata pada permukaan kanvas. Hal ini memperkuat kesan impresi di samping sapuan garis yang ekspresif. Teknik lapisan warna pada lukisan oleh Arifin terkesan menghendaki lapisan 
warna under-painting yang tua dan gelap, selanjutnya disapukan warna cerah yaitu kuning dan putih secara bertumpuk. Demikian, hal ini menghasilkan efek chiaroscuro yang estetis.

Prinsip keseimbangan pada lukisan Malin Deman II digarap dengan intensitas unsur rupa yang imbang antara sisi kiri dan kanan lukisan dengan objek utama ditonjolkan pada bagian tengah lukisan. Keseimbangan dapat dirasakan pada permainan posisi konfigurasi objek dan permainan keseimbangan semu pada warna gelap terang di sisi kanan serta kiri lukisan. Penggambaran proporsi antara objek yang satu dengan yang lainnya dalam lukisan tersebut divisualkan dengan ideal dan tampak wajar, sehingga tidak menimbulkan keganjilan saat diamati. Misalnya pada penggambaran proporsi objek manusia yang digambarkan dengan proporsi alam sekitarnya. Sedangkan irama komposisi objek manusia yang digarap terasa dinamis, namun tetap terlihat longgar, dan tidak monoton.

Tahap deskripsi praikonografi juga memerlukan kerangka konfirmasi dengan prinsip korektif berupa sejarah gaya. Panofsky mengemukakan, tahap ini memerlukan pengkoreksian dan pengujian sejarah gaya dengan cara mengidentifikasi karya dari perspektif sejarah, di mana, dan dalam kondisi sejarah seperti apa objek serta peristiwa diungkapkan ke dalam bentuk visual (Panofsky, 1955: 35).

Sejarah tidak akan terlepas dari konstruksi waktu (temporal) dan ruang (spasial)-nya (Kartodirdjo, 1993: 18-19). Untuk mengetahui sejarah gaya pada lukisan ini, dapat dirunut dari kapan lukisan ini dibuat. Berdasarkan sejarah gaya, pelukis pada periode 2000-an sudah mulai bergeser pada praktik seni rupa kontemporer, seperti mendobrak dan meleburkan sekat medium, teknik, gaya, serta batasan seni dengan berbagai kemungkinan yang bersifat lebih eksploratif dan eksperimental.

Namun, Arifin adalah salah satu seniman yang masih mempertahankan gaya ketepatan objek dan fantasi yang berrepresentasi naturalistik. Pada periode tersebut tidak banyak para pelukis Sumatra Barat yang memiliki kecenderungan gaya ungkap demikian terutama pada seniman generasi muda. Sebagian besar seniman tahun 2000-an sudah mulai menggunakan berbagai media ungkap yang tidak lagi bersifat konvensional. Sebaliknya kecenderungan naturalistik dengan mengangkat tema-tema lokal yang bertumpu pada cerita-cerita klasik dari Sumatra Barat terutama pada lukisan yang berjudul Malin Deman II masih dibawa Arifin untuk eksis di tengah maraknya perkembangan seni kontemporer di Sumatra Barat.

\section{Analisis Ikonografi}

Tahap selanjutnya adalah analisis ikonografis. Tahap analisis ini menginterpretasi makna sekunder yang konvensional berdasarkan imaji, cerita atau studi literatur, dan alegori/ lambang sehingga dapat mengidentifikasi tema dan konsep karya (Panifosky, 1955: 35). Tahap ini merupakan tahap untuk mengidentifikasi pembacaan aspek tekstual (motif artistik) dengan melihat hubungan antara motif sebuah karya seni dengan tema dan konsep yang dimanifestasikan dalam bentuk gambar, sastra, alegori atau perlambangan yang ada pada karya.

Tahap analisis ini juga membutuhkan rasa familiar dengan objek dan peristiwa yang divisualkan pada karya berdasarkan pengalaman praktis penulis sehingga dapat dianalisis 
tema dan konsep yang tersirat. Hal ini dapat diperoleh dari sumber-sumber literal. Selanjutnya, tahap ini akan dikoreksi dengan prinsip korektif sejarah tipe.

Tahap analisis ini menggunakan teori semiotika Roland Barthes sehingga pertanda yang muncul dari lukisan dapat di gali mitos yang dapat mengungkap lambang/alegori di balik karya tersebut. Selanjutnya mitos yang terdapat di balik kehadiran petanda dalam karya dapat dihubungkan dengan tema dan konsep yang tersirat. Mitos dalam pengertian semiotika Barthes tidak sama seperti pengertian mitos secara umum yang diyakini oleh masyarakat terdahulu terhadap suatu cerita maupun peristiwa. Roland Barthes membahas mitos lebih serius pada bukunya yang berjudul Mythologies di bagian Myth Today tahun 1972. Dalam konteks pengertian mitologi lama, mitos bertalian dengan sejarah dan bentukan masyarakat pada masanya, tetapi Barthes memandangnya sebagai bentuk pesan atau tuturan komunikasi massa pada dunia modern yang terselubung di balik maksud secara permukaan.

Bagi Barthes, tuturan mitologi bukan saja berbentuk tuturan oral melainkan dapat pula berbentuk tulisan, fotografi, film, laporan ilmiah, olah raga, pertunjukan, bahkan iklan dan lukisan yang menjelaskan makna tersembunyi dari komunikasi berkembang. Hal yang harus diperhatikan bahwa mitos adalah suatu sistem komunikasi, yakni suatu pesan (message). Tetapi mitos tidak didefinisikan oleh objek pesan melainkan dengan cara menuturkan pesan tersebut. Apa saja bisa dikatakan sebagai mitos selama dituturkan dalam bentuk wacana/diskursus. Pengertian mitos dalam konteks ini bukan mitologimitologi lama mempunyai pengertian suatu bentukan dari masyarakat yang berorientasi pada masa lalu atau dari bentukan sejarah yang bersifat statis, kekal. Melainkan sebuah gejala komunikasi massa yang dituturkan dalam bentuk wacana/diskursus yang menyiratkan sesuatu makna tersembunyi dalam konteks gejala yang terjadi pada lingkup dunia modern. Bentuk tuturan wacana tersebut dalam hal ini dikaji dalam wujud karya seni rupa yaitu petanda yang hadir pada representasi sebuah lukisan. Demikian ini bisa diketahui tema dan konsep di dalam petanda-petanda yang dihadirkan dari lukisan Malin Deman II.

Lukisan Malin Deman II merupakan hikayat yang berasal dari Sumatra Barat. Namun, pada beberapa daerah juga dapat ditemukan cerita demikian dalam berbagai versi judul yang berbeda. Salah satunya cerita ini memiliki kemiripan dengan kisah cerita rakyat Jawa Tengah, yaitu Jaka Tarub. Berdasarkan alur cerita, Malin Deman merupakan salah satu tokoh yang diceritakan tanpa sengaja menemukan dan mengamati tujuh bidadari yang sedang mandi pada sebuah sungai. Karena terpikat, Malin mengambil salah satu selendang milik tujuh bidadari yang berada di pinggiran sungai. Visualisasi tersebut dapat diamati pada representasi seorang pria yang ingin mencuri salah satu selendang dari tujuh bidadari dengan gestur yang hendak menjangkau sehelai selendang putih yang berada di pinggir sungai dengan tangan kanannya. Sikap untuk hendak mencuri selendang secara diam-diam terlihat dari figur pria yang dilukiskan berada di balik pohon dan semak dekat dengan pemandian tujuh perempuan dalam lukisan.

Menurut pada cerita Malin Deman dalam cerita rakyat nusantara yaitu di Sumatra Barat, maka di dalam karya tersebut terdapat penggabungan narasi yang dibuat berdasarkan versi Arifin. Lukisan ini memvisualisasikan fantasi dari refleksi persepsi 
Arifin. Sosok pria dalam lukisannya dikaitkan tokoh yang terdapat dalam salah satu kisah sastra lama/kaba klasik rakyat Minangkabau yang berjudul Malin Deman.

Malin Deman merupakan seorang pemuda yang giat bekerja dan memiliki budi baik. Ia dikisahkan tinggal di Kampung Tibarau, Batang Mua. Tokoh tersebut berdasarkan cerita yang berhasil mencuri selendang dari salah satu bidadari paling bungsu tanpa sepengetahuan para bidadari yang sedang mandi di sebuah sungai bernama Lubuak Kamuniang Gadiang (Manggis, 2015: 5). Namun, di dalam lukisannya, Arifin melukiskannya dengan narasi yang berbeda. Malin justru dilukiskan ketahuan mencuri salah satu selendang dari tujuh bidadari yang sedang mandi tersebut. Hal ini terlihat dari gestur tubuh para bidadari yang dilukiskan kalang kabut dan ingin segera beranjak dari pemandian mereka. Gestur tubuh tujuh perempuan yang dilukis Arifin memperlihatkan ekspresi kepanikan dan menyelamatkan masing-masing selendangnya.

Demikian, terdapat upaya Arifin untuk didekonstruksi dengan alegori tertentu pada lukisan Malin Deman II-nya. Ia dalam karya lukisan tersebut mengungkap sesuatu hal yang tidak lagi mengutamakan sesuatu yang telah mapan sebagai konsep dalam berkarya. Di era post-modern ini, segala sesuatu bisa didekonstruksi ulang dan tidak lagi mementingkan suatu batasan yang dahulunya dikotakkan. Ide dan tema lebih berani disuarakan oleh para seniman dalam berkarya termasuk mendekonsruksi isu dan hal-hal apapun yang telah mapan. Hal tersebut dapat dilihat dari yang dilakukan Arifin pada karyanya ini. Ia tetap berada pada penggarapan visual karya yang naturalistik, namun secara konsep ia telah berani keluar dari nilai-nilai konvensi pada pelukis-pelukis modern di Sumatra Barat pada masanya yang kerap menggambarkan alam dan kehidupan masyarakat yang elok tanpa menghadirkan tubuh-tubuh setengah nute yang sebaliknya dilakukan Arifin.

Berdasarkan sumber literatur tersebut dan visual yang tampak, maka tema dari lukisan Malin Deman II dapat diklasifikasikan dalam bentuk alegori termasuk pada pengungkapan penindasan kaum laki-laki terhadap kaum perempuan lewat kekuasaan simbolik yang mereka miliki. Selanjutnya, pemaparan tema lukisan Malin Deman II yang telah dirunut dari sumber mitologi dan sastra, maupun imaji serta alegori, dapat diketahui konsep yang dijadikan penciptaan lukisan tersebut adalah konflik gender. Posisi perempuan seperti yang terdapat dalam visual lukisan Arifin, divisualisasikan berada dalam posisi yang lemah. Hal ini dilihat dari penggambaran tujuh perempuan yang terkejut bahwa ada yang mengitip mereka sedang mandi kemudian hendak mencuri salah satu selendang mereka tanpa melakukan perlawanan, dan memilih segera meninggalkan tempat pemandian tersebut.

Ketajaman analisis ikonografi dapat dilakukan dengan konfirmasi prinsip korektif interpretasi sejarah tipe. Sejarah tipe merupakan kondisi sejarah yang memengaruhi konvensi suatu tema dan konsep yang diekspresikan dalam objek-objek dan peristiwa spesifik pada suatu masa dan wilayah (Panofsky, 1995: 40). Konvensi tema dan konsep tentang konflik yang diperoleh pada tahap sebelumnya, serta simbol kekuasaan pria sebagai hirarki atas yang menindas hak perempuan seperti dalam lukisan Malin Deman II. Berdasarkan nilai lokalitas yang diangkat pelukis ke dalam karyanya, gejala ini terdapat dalam ranah adat Minangkabau. Walaupun di dalam adat Minangkabau kedudukan wanita lebih ditinggikan, seperti yang kerap disebut dengan nama Bundo Kanduang, namun hal 
tersebut telah terjadi pergeseran. Di sisi lain kaum perempuan masih ditemukan mengalami penindasan.

Seperti yang terlihat dalam karya Arifin. Berdasarkan sejarah tipe pada masa pelukis Arifin eksis di Sumatra Barat, sekitar tahun 80-an mulai adanya kesadaran untuk mengkritik realitas sosial ke dalam karya lukis melalui representasi alam atau lingkungan yang dianalogikan pada objek-objek tertentu. Berbagai tema dan konsep tersebut merupakan pengembangan dari tema-tema realis kehidupan sosiokultural dari masa-masa sebelumnya.

Karya-karya tipe sejenis dapat dilihat dalam lukisan Kamal Guchi, pelukis era 80-an yang masih tetap eksis dengan tema-tema Minangkabau hampir sama dengan pelukis Arifin. Kamal Guchi kerap mengangkat rumah gadang yang berdiri rapuh seperti dalam karyanya Terlupakan III (2012) dan Si binuang Patah Tanduak (2012). Lukisan menggambarkan kemirisan dari pergeseran dan nasib adat serta kultur Minang yang kerap dilukiskan melalui analogi rumah gadang dan simbol-simbol kebesaran Minangkabau lainnya. Selain itu, hal ini juga terdapat lukisan karya Darvies Rasyidin Dialog empat perempuan (2000), dan Pemusik (2000).

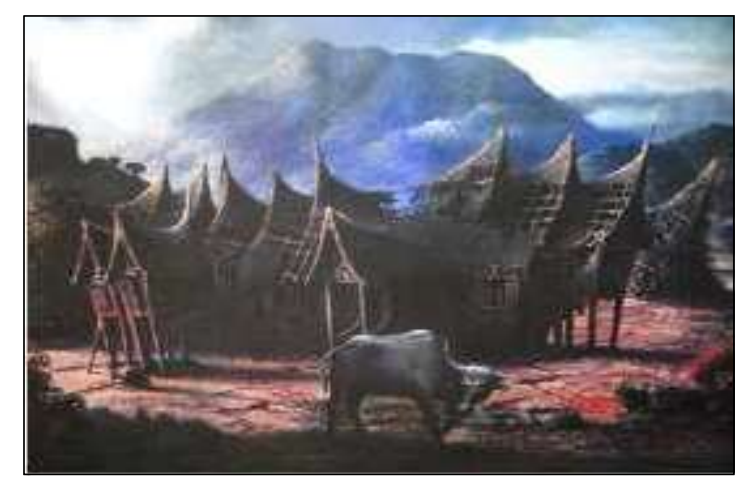

Gambar 2. Si Binuang Patah Tanduak (2012) cat minyak di atas kanvas, 100x140 cm Sumber : Katalog pameran tunggal kamal guci (Foto reproduksi : penulis, 2015)

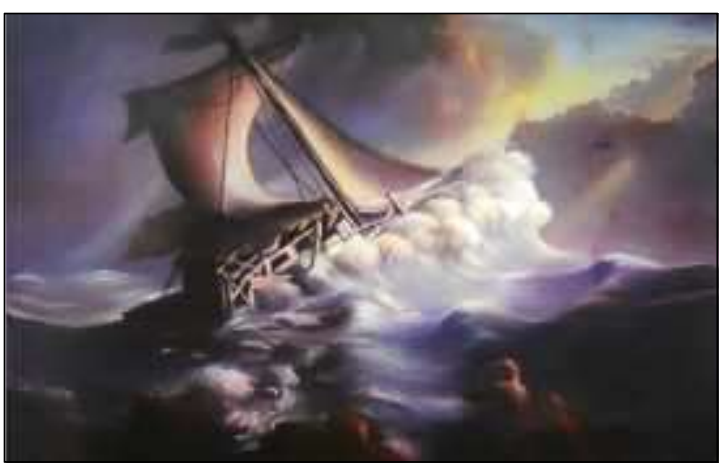

Gambar 3. Malin (2012)

cat minyak di atas kanvas, 100x140 cm Sumber : Katalog pameran kamal guci (Foto reproduksi : penulis, 2015) 


\section{Interpretasi Ikonologi}

Tahap terakhir adalah tahap interpretasi ikonologi (makna intrinsik atau isi). Tahap ini adalah tahap yang paling esensial yaitu terkait dengan makna intrinsik atau isi dari sebuah karya seni. Tahap ini dibutuhkan kemampuan intuisi sintesis untuk memahami simbol. Intuisi sintesis menyangkut tendensi esensial pemikiran psikologi personal dan weltanschauung (pandangan hidup) seniman. Tahap ini dibutuhkan prinsip korektif interpretasi sejarah kebudayaan yang membentuk simbol-simbol di dalam karya seni untuk mencapai ketajaman interpretasi. Ini dilakukan melalui simtom yang ada di sekitar objek maupun seniman dengan merujuk pada pandangan hidup masyarakat penyangganya (Panofsky, 1955: 41).

Berbagai kecenderungan untuk melakukan perubahan dan perkembangan secara individu dalam sejarah perjalanan seni lukis di Sumatra Barat mulai tumbuh dengan gaya personal sekitar tahun 70-an. Namun, seniman di Sumatra Barat masih kerap tidak terlepas dari tema-tema kultural Minang menjadi sumber penciptaan. Pelukis periode 70 sampai 80-an di Sumatra Barat telah mulai memperlihatkan keragaman pemikiran dan kesadaran berkreasi dalam karya baik dalam konsep, tema dan gaya karya. Hal tersebut semakin terlihat dari munculnya nama-nama pelukis beserta karyanya yang tidak lagi berpatokan pada aliran dan gaya Wakidi-an.

Sebelumnya, konsep estetik yang berkembang masih melihat alam sebagai cerapan indrawi sebagai objek sentral, serta masih mementingkan kecermatan dan olah teknis melalui kejelimetan pemilihan warna berdasarkan warna ada di alam. Hal ini selanjutnya mengalami pergeseran dan muncul kesadaran seniman untuk lebih leluasa terbebas dari permainan warna yang mengikuti tren gaya Wakidi (Rossa, 2004: 7- 8). Pergeseran tersebut juga dapat diamati pada karya-karya seniman seangkatan Arifin di antaranya Darvies Rasyidin, dan Kamal Guci. Mereka tidak lagi berpatokan dengan sapuan kuas yang lembut dan warna-warna yang lembut seperti estetik yang diperkenalkan oleh Wakidi.

Sebagian besar seniman mulai lebih kritis dalam memilih konsep dalam karyanya yang tidak lagi memandang alam, sosial budaya sebagai sesuatu yang estetik dan molek. Perubahan tersebut sudah mengarah pada kritik sosial dan budaya yang melambangkan atau menyimbolkan fenomena sekitar seniman yang miris. Hal ini juga terlihat pada pandangan Arifin dalam berkarya. Pemikiran Arifin dalam berkarya lebih melihat kegelisahan persoalan-persoalan sosial, esensi adat, dan tingkat laku masyarakat Minangkabau yang tidak sesuai dengan perilaku kehidupan adat, seperti tantanan intelektual, etika dan keyakinan yang dimiliki dalam masyarakat. Pada pelukis sezamannya (periode tahun 70 hingga 80 -an) Arifin merupakan satu di antara seniman yang tetap bertahan dengan gaya naturalis dan realistik di samping seniman kontemporer yang mulai banyak bermunculan dengan kecenderungan berkarya yang lebih bebas. Seniman generasi 2000-an yaitu di tengah eksistensi Arifin yang tetap bertahan dalam praktik berkesenian, lebih cenderung melakukan penyadaran terhadap kemirisan kondisi sosial dan politik serta dampak globalisasi khususnya isu lokal maupun global yang terjadi tidak hanya tema-tema Minangkabau melalui berbagai media seni dalam berkarya. 
Berkaitan dengan berbagai latar gejala sosial dan kultural yang terjadi, maka dapat diketahui lukisan Malin Deman II A. Arifin merupakan kristalisasi simbol-simbol kemirisan esensi adat dan secara tidak langsung upaya penyadaran kepada masyarakat. Langer menjelaskan, simbol seni disebut juga citraan absolut, yaitu citra yang menjadi rasional karena secara harfiah tidak tergambarkan. Sedangkan simbol di dalam seni merupakan arti perlambangan yang dimuat pada karya tersebut, atau sebuah metafora (Langer, 2006: 138 - 153). Maka, figur-figur yang memiliki narasi dalam lukisan Malin Deman II-nya merupakan sebuah metafor penghayatan Arifin terhadap realitas dan empati pada kondisi sosial masyarakat di sekitarnya dan esensi adat yang mulai pudar termasuk gejala sosial penindasan terhadap kaum perempuan.

Hal ini menjadi motif artistik Arifin dalam melahirkan karya yang dikaji ini. Senada dengan yang diungkap Pamola, secara keseluruhan bagi Arifin perempuan yang kerap ia lukis dalam karyanya ia ibaratkan seperti air yang memiliki peran penyeimbang alam dan hidup. Sedangkan alam pada karyanya diinterpretasikan sebagai penyejuk dan sumber kehidupan dengan pemaparan hutan dan gunung secara landspace (Pamola, 2013 : 12).

Tahap ikonologi membutuhkan prinsip korektif sejarah gejala kultural di bawah kondisi sejarah yang bervariasi, tendensi umum dan esensial dari pikiran manusia yang dinyatakan melalui tema dan konsep (Panofsky, 1995: 41). Maka diperlukan ditinjauan berbagai simtom yang ada di sekitar objek maupun penciptaannya, yang merujuk pada psikologis dan pandangan hidup masyarakat penyangganya. Berdasarkan kerangka konfirmasi tersebut, lukisan Malin Deman II merupakan ekspresi Arifin dalam merefleksikan nilai-nilai kebudayaan yang mulai memudar dan pandangan ideologisnya melihat berbagai fenomena yang dirasakan. Jika menurut pada gejala kultural dan pandangan hidup masyarakat penyangga pada saat lukisan tersebut dibuat, yaitu pada tahun 2013, hal ini dapat diamati menyinggung nilai-nilai filosofis adat Minangkabau yang mengalami perubahan dan luntur, khususnya terjadi di kalangan generasi muda.

Nilai-nilai itu secara spesifik berkaitan dengan makna dan hakikat hidup, yang meliputi hidup berbudi, hidup berkerukunan, hidup bermalu dan hidup berpendirian terutama di kalangan perempuan dan kaum laki-laki dalam bertingkah laku dan saling hormat menghormati. Persoalan budi pekerti atau akhlak juga yang disebut moral telah mengalami degradasi yang sangat dalam, sehingga hampir semua krisis yang terjadi pada zaman temporer ini berpangkal dari krisis moral. Seperti yang disinggung Arifin di dalam lukisannya, kalangan budayawan menyebut hal ini sudah berada diambang kebangkrutan kultural. Penyebabnya adalah melemahnya ikatan adat dan tradisi.

Selanjutnya, terdapat tantangan globalisasi khususnya pada kalangan perempuan. Di tengah arus globalisasi saat ini, pola kehidupan masyarakat Minangkabau sudah bertukar dengan menyesuaikan diri dengan eranya. Sebelumnya, khususnya di Minangkabau, kehidupan sosial dijalani dengan keluarga besar di rumah gadang kini sudah diganti dengan keluarga inti, yang terdiri dari ayah, ibu, dan anak. Posisi perempuan dalam keluarga tidak lagi seperti di rumah gadang. Jika dalam sistem matrilineal yang dianut Minangkabau perempuan memegang posisi terpenting di rumah gadang, saat ini di dalam keluarga inti di kehidupan keluarga mulai bergeser menyesuaikan nilai-nilai global. Lakilaki sebagai kepala keluarga yang menentukan semua kebijakan rumah tangga. 
Dampak berkembangnya globalisasi di Minangkabau dan juga di perantauan, tampaknya memberi kontribusi yang cukup dominan untuk melemahkan posisi perempuan di Minangkabau dan sebagai determinatif yang cukup signifikan. Posisi perubahan strata inilah yang disimbolkan dalam lukisan Arifin Malin Deman II. Hal ini terlihat dari karya Arifin yang memperlihatkan kekuasan seorang Malin saat mencuri selendang salah satu dari tujuh perempuan yang sedang mandi di sungai tersebut, tanpa terlihat gestur melakukan perlawanan.

Saat ini kehidupan sehari-hari masyarakat lokal justru sangat dipengaruhi oleh polapola kehidupan masyarakat global dan budaya global. Pengaruh tersebut telah merubah cara hidup, gaya hidup bahkan pandangan hidup masyarakat, yang pada titik tertentu justru mengancam eksistensi warisan adat, kebiasaan, simbol, identitas dan nilai-nilai budaya lokal. Berlatar belakang sejarah kebudayaan tersebut di atas dengan melihat berbagai simton psikologis, pandangan hidup Arifin terhadap sikap konsistennya dalam berkarya, dan melihat tema serta visualisasi karyanya, maka lukisan Malin Deman II menjadi simbol ungkapan ketertindasan kaum perempuan dan disposisi perempuan dalam konteks kebudayaan di Minangkabau.

\section{Kesimpulan}

Kesimpulan terhadap kajian lukisan Malin Deman II karya Arifin berdasarkan kajian ikonografi dan ikonologi Panofsky adalah pertama, pada tahap deskripsi ikonografi, makna faktual dalam karya tersebut adalah adegan seorang laki-laki yang mengintip tujuh orang perempuan yang sedang mandi di sungai. Sedangkan makna ekspresionalnya adalah kegairahan laki-laki yang bernama Malin mengintip dan hendak mencuri salah satu selendang dari tujuh perempuan dalam lukisan tersebut.

Motif artistik yang didapat adalah fantasi pelukis terhadap cerita klasik Minangkabau Malin Deman yang hendak ingin didekonstruksi dengan pola representasi gestur tubuh perempuan yang dilukiskan dengan komposisi yang artistik dan seimbang. Kedua, tema dan konsep pada lukisan tersebut mengungkap tema penindasan kaum laki-laki terhadap kaum perempuan lewat kekuasaan simbolik yaitu selendang sebagai perwakilan dari kepemilikan perempuan. Demikian, diketahui konsep dari visual karya tersebut yaitu konflik dan pergeseran peran antara gender yaitu antara posisi laki-laki dan perempuan di Minangkabau. Ketiga, nilai-nilai simbolik yang diungkapkan dalam karya tersebut adalah metafor penghayatan seniman terhadap realitas dan empati kondisi sosial masyarakat termasuk esensi adat yang mulai pudar khususnya fenomena perempuan di Minangkabau pada era temporer ini.

Melalui kajian ikonografi ikonologi ini didapatkan bahwa seniman dalam mengekspresikan konsep pemikirannya dalam karya seni khususnya seni rupa memang tidak terlepas dari konteks zaman yang sedang berlangsung pada masanya. Namun hal berbeda masih terdapat pada beberapa seniman yang justru menentang arus zaman yang berlangsung di tengah keberadaan orisinalitas karyanya sehingga menimbulkan suatu muatan simbolik yang khas dan berbeda secara spesifik. Selain kajian ikonografi dan ikonologi dapat mengungkapkan kecenderungan makna yang tersebunyi di balik 
kehadiran komponen bentuk karya seni juga dapat memperlihatkan konteks sejarah tipe dan sejarah gaya yang mempengaruhi proses penciptaan seorang seniman dalam berkarya.

\section{Kepustakaan}

Barthes, Roland. 2004. Mitologi, terj. Nurhadi \& Sihabul Millah, kreasi wacana, Yogyakarta

Feldman, Edmund Burke. 1967. Art as Image and Idea atau Seni sebagai ujud dan gagasan terjemahan Sp. Gustami, 1991, Fakultas Seni Rupa dan Desain Institut Seni Yogyakarta, Yogyakarta.

Langer, Suzanne K. 2006. Problems of Art atau Problematika Seni, terjemahan FX. Widaryanto, Sunan Ambu Press, Badung.

Manggis, M.Rasyid. 2015. Kaba Klasik Minangkabau : Kaba Malin Deman, Kristal Multimedia, Bukittinggi.

Panofsky, Erwin. 1955. Meaning in The Visual Arts. the university of chicago press, chicago.

Katalog. 22 - 30 September 2006. "Pameran Lukisan 150 Tahun Seni Rupa Sumatra Barat : Ngarai Sianok Differenza in Dentro Uno Passa", Gedung Perpustakaan Bung Hatta, Bukittinggi.

Katalog. 30 Oktober - 8 November 2013. "Pameran Tunggal A.Arifin : Re-Inventing Minangkabau", Rumah Budaya Fadli Zon, Padang Panjang. 